\section{Higher Education Systems and the Tuition Fees Charging: Perspectives and Perceptions in Brazil, Canada and China}

\author{
Danilo de Melo Costa ${ }^{1,+(1)}$ \\ ${ }^{1}$ Centro Universitario Una, Belo Horizonte, MG, Brazil \\ Francisco Vidal Barbosa 2, (1D \\ ${ }^{2}$ Universidade Federal de Minas Gerais, Belo Horizonte, MG, Brazil \\ Qiang Zha ${ }^{3, ¥}$ (D) \\ ${ }^{3}$ York University, Toronto, Ontario, Canadá \\ Roopa Desai Trilokekar ${ }^{4, *(1)}$ \\ ${ }^{4}$ York University, Toronto, Ontario, Canadá
}

\section{ABSTRACT}

This study aims to understand the perceptions of the tuition fees charging in Canada and China and the perspectives of this practice in Brazil, which is a country where society requires access to quality higher education, but which faces large budgetary constraints on its public funding. To understand these questions, a qualitative exploratory multi-case study was carried out with government officials, specialists in higher education, and student leadership from all three countries. In conclusion to this analysis, and considering the benefits provided by the Canadian and Chinese participants, it is suggested for Brazil to perform a reflection on this subject. The study shows that such an initiative can boost public higher education institutions through greater financial availability and democratize access and permanence, as there would be more resources to invest and assist students from underrepresented groups participating in the system.

Keywords: Public financing; Higher education; Tuition fees; Expansion; Public policy

\section{INTRODUCTION}

The importance of the variable "education" has been considered by several countries, since it is often associated with the progress of a country. This development through investment in higher education was already confirmed in Canada, which for many years has invested heavily in education, achieving significant rates of young people between 18 and 24 years enrolled in higher education (HADDAD; GRACIANO, 2004). In that scenario, Canada stands out not only quantitatively but also qualitatively, being one of the highest quality country regarding higher education worldwide.

In Asia, the continent grows as much as it invests in education. In recent years, Asians discovered this formula of success and began to invest heavily both in basic education and in higher education.
Corresponding author:

† Centro Universitario Una, Belo Horizonte, MG, Brazil

E-mail: danilomct@gmail.com

$\Omega$ Universidade Federal de Minas Gerais, Belo Horizonte, MG, Brazil

E-mail: fvberlim@gmail.com

$¥$ York University, Toronto, Ontario,

Canadá

E-mail: qzha@edu.yorku.ca

*York University, Toronto, Ontario,

Canadá

E-mail: rdesaitrilokekar@edu.yorku.ca

Received: 01/17/2018.

Revised: 03/06/2018.

Accepted: 05/04/2018

Published Online: 11/28/2018.

DOI: http://dx.doi.org/10.15728/bbr.2019.16.2.3 
Countries like China have been carrying out research within their own universities and then commercializing the results, as well as increasing investment in higher education (MAHMOOD; SINGH, 2003).

In South America, with emphasis on Brazil, the most prominent universities receive state public funding, not federal (University of São Paulo (Universidade de São Paulo, USP) and the University of Campinas (Universidade de Campinas, Unicamp)). This is due to the still inadequate investment regarding public funding for higher education (WEBOMETRICS, 2015; ARWU, 2015; HEEACT, 2015).

For this reason, Brazilian society demands access to quality higher education that can meet this need, which generates the need to study new forms of public funding. Therefore, this study tries to seek new alternatives for management and financing through initiatives already implemented and consolidated in other countries, in this case Canada and China, aiming to assist in solving a chronic problem faced by Brazilian higher education.

The choice of these countries for the study is based on their experience with the tuition fees charging:

- Canada is a country that has charged tuition fees for more than 50 years, and has seen a large increase since 1984;

- China is a country that started to charge tuition fees from 1997 on and during this period promoted a revolution, possessing nowadays the largest educational system in the world;

- Brazil is a country that faces significant budgetary constraints and has been struggling to improve higher education indicators, especially in terms of increasing the number of young people aged 18 to 24 enrolled in higher education.

Would Brazilian public universities be ready to charge tuition fees? How did the tuition fees charging help in the Canadian and Chinese systems development?

To answer these questions, a research was performed with government managers, specialists in higher education, and students' leadership from all three countries, in order to clarify a subject still paradigmatic in the scope of Brazilian public higher education.

\section{WORLD HIGHER EDUCATION CHALLENGES}

At the end of the first decade and the beginning of the second decade of this century, many nations, especially the developed ones, faced one of their greatest financial crises. Continents hitherto economically sound, as North America and Europe are the main affected, especially the United States, which shall have its hegemony threatened by China (SAWAYA, 2009). That situation makes these continents start to rethink a number of structural changes.

Amid the unwanted situations, some instruments are now considered essential to improve economic indicators, including higher education, which is responsible for several factors that have a direct impact on the results of the economy, such as:

a. generation of skilled labor, which causes direct impact on productivity and consequently in job creation; 
BBR

16,2

b. innovation discoveries, which can also help in the economic progress of countries and generating jobs;

c. creation of new business and maintaining existing business, by training entrepreneurs (EUROPEAN COMMISSION, 2011).

Factors such as these cause nations start paying even more attention to higher education and funding, which should be allocated for countries such as the United States, which has always been regarded as an innovative nation, mainly due to Silicon Valley's results. That nation begins to worry not only about generating technological innovations, but mainly about marketing the innovations that have been developed to reach favorable economic results. This concern is due to the speed at which Asians have been playing such innovations and then the marketing for the rest of the world, something easily possible after globalization (ERNST, 2005).

In Europe, higher education is now also one of the main instruments. The main adversity faced by countries concerns to high unemployment, which can be minimized with the generation of skilled labor, influencing productivity, and the training of entrepreneurs. Undertaking results in job creation, something that is critical to the economic performance of European countries in the coming decades (EUROPEAN COMISSION, 2011).

On the other hand, continents like South America and Asia, especially countries such as Brazil, China and India, have been living a moment of progress, being considered the main emerging economies. The crisis affecting developed countries eventually makes room for the growth of emerging countries that understood the importance of higher education and have gradually improved their indicators. Investments in education have a direct impact on innovation; we can see in oil exploration, or in producing software or even electronic equipment, measures which are responsible for the good results of the countries (ARMIJO (2007).

The aforementioned information show the significance of the effects of globalization worldwide, with a profound impact on education (especially in higher education) and financing that composes it.

\subsection{The EFFECTS OF GLOBALIZATION ON HIGHER EDUCATION AND ITS FINANCING}

From globalization, there is a worldwide need for higher levels of education, resulting in a large increase in demand and access of students seeking the higher education. Ilon (2010) shows that between 1975 and 1995 there was a considerable increase in students enrolled in higher education in the world, out of 40.3 million, going to 80.5 million, almost doubled in just 20 years.

Delimiting the developed countries, Lazerson (2010) argues that globalization was responsible for promoting competition for financial resources between countries and universities, promoting changes in their funding. This type of globalization, from the scientific and technological developments, now called economic globalism, seeks to produce greater capital accumulation and has a strong influence on capitalism. (TÜNNERMANN BERNHEIM, 2010). 
This variation of globalization then goes on to influence higher education, which must conform to this new global reality, in order to produce knowledge that is commercial, affecting traditional academic activities, began being guided by the requirements of applicability and market value. Tünnermann Bernhim (2010) criticizes this influence, saying that the instrumental knowledge, if applied indiscriminately, will cause new and complex problems, citing the environment deterioration as an example. For Didriksson (2000), it is explicit the economic character that has higher education, in that it has a particular relationship with the production of knowledge related to the industry. The author adds saying that much of the knowledge produced aims at contributing to economic support, being described as a close relationship. As already noted, the scientific and technological innovations depend on many factors that are arising in many cases from research centers, which are beyond the own production system. The existing direct relationship between science, production and technology, generates a set of new categories that suggest major changes in the tertiary education financing, appreciation of intellectual work and knowledge that are seen as economic values.

From the structural changes presented above, Carnoy and Rhoten (2002) describe that the financing of higher education began to receive a large investment from the private sector, especially in countries like the United States and the United Kingdom (which meant the decrease financial support from the Federal Government). On the other hand, the authors argue that the Federal Government's participation in the higher education financing in the East Asian countries has increased considerably, demonstrating a steady commitment to improving the quality of higher education institutions, which are now seen as one of the main factors for the progress of countries.

As a result of these investments, one third of the world's best universities are located in the Asia Pacific region, being observed a large government intervention in emerging Asia (CARNOY; RHOTEN, 2002). Countries like Taiwan, South Korea and especially China have been increasing funding to their universities aimed at increasing the number of universities with world-class. The Academic Ranking of World Universities itself, prepared by the University of Shanghai Communications (Jiaotong) was created so that the Chinese universities could understand what has been done in the world's premier universities. Ilon (2010) shows that the numbers in these countries are amazing when noting that Asia has made almost twice more engineers than Europe, a professional area that has a certain shortage of skilled labor currently qualified, representing the important role that higher education has played in world economies.

Finally, in order for a country to succeed in meeting these challenges, it is necessary for its government to take on the responsibility of improving the results and to make the necessary interventions, subject matter in the next topic.

\subsection{GOVERNMENT INTERVENTION AND ITS ECONOMIC RESPONSIBILITIES}

The Federal Government presents itself as a key player to meet the society's needs, given its interference in economic, political and social activities. This intervention is possible because the Federal Government presents itself as a regulatory body, seeking to hold a development promotion, a fair income distribution, maintaining the economy's 
BBR

16,2

stability, and still, in seeking to provide goods and public services to society. The state intervention with development models are intended to positively influence the element orientation in the short and long-term dynamics of a nation, state or county. Among all state responsibility actions, some stand out, such as: security; employment; welfare; and education. These actions aim to reduce violence, social inequality and improve the population's quality of life (MATIAS-PEREIRA, 2006).

Tax collection then becomes the main tool in order to maintain the proper balance of the public system by the private system growth. Longo (1984) shows that both in the United States and Brazil, almost one third of all collected income comes from taxes. In some Scandinavian countries, this collection is even higher, exceeding $40 \%$. This taxes collection, which marks a strictly budgetary role, is the main influence of the Federal Government to the course of economic activities by means of conducting monetary policy, state enterprises management, regulation of private administrative responsibility of companies, price and inflation control policies, among others.

In the economy, Federal Government intervention can happen in different ways. Among all, five should be highlighted:

a. form a legal basis;

b. keep non- distortionist policies (keeping economic stability as well);

c. invest in basic services and that makes up the infrastructure;

d. support vulnerable groups;

e. protect the environment (BANCO MUNDIAL, 1997).

In addition, the Federal Government should also play an important role in the opening of trade, technological innovation, communication and promotion of national consensus (MATIAS-PEREIRA, 2006), something that for Lerda, et al. (2005) must be performed with greater efficiency and effectiveness, as they will be responsible for providing better service provision to the population.

The Federal Government intervention in developing countries such as Brazil, China, India, among others, is usually based on ideological reasons or because the private sector was not able to make the necessary investments for the development of a sector. In Brazil, Giambiagi and Além (2001), believe that greater Federal Government intervention in the Brazilian economy had to supplement the private sector actions for the country's development. For the Brazilian higher education, public policies can be analyzed such as Fies, Prouni, and Reuni Uab, which aimed to equalize the participation of public funding from the private sector, which has expanded considerably after LDB/96.

Finally, government intervention is leading to ensure success in all levels of education, including higher education, which in recent decades had its role driven by the benefits associated with the nations' progress.

\section{METHODOLOGY}

In this research, due to the objectives, the study was developed as an exploratory research. For Collins and Hussey (2005), the exploratory research should evaluate which theories or concepts can be applied to a relevant problem, or if new concepts and theories can be developed. From then on, such study is characterized as exploratory for seeking to 
Chart 1 - Interviewees: government managers

\begin{tabular}{|c|c|c|c|c|c|}
\hline \multicolumn{6}{|c|}{ Government managers - Canada interviewees } \\
\hline Denomination & Agency & City & Date & Schedule & Obs. \\
\hline Interviewee 1 & CMEC & Calgary & Mar 30th. 2014 & 01:00 to $02: 20$ p.m. & Video-conferência \\
\hline Interviewed 2 & $\mathrm{COU}$ & \multirow{4}{*}{ Toronto } & Feb 05th. 2014 & 02:00 to $03: 30$ p.m. & \multirow{4}{*}{ Presencial } \\
\hline Interviewee 3 & MTCU & & Mar 28th. 2014 & 09:00 to $10: 00$ a.m. & \\
\hline Interviewee 4 & HEQCO & & Feb.10th 2014 & $10: 30$ a.m. to $12: 30$ p.m & \\
\hline Interviewee 5 & HESA & & Feb.19th 2014 & 03:00 to $04: 30$ p.m. & \\
\hline \multicolumn{6}{|c|}{ Government managers - China interviewees } \\
\hline Interviewee 6 & MOE/NCEDR & \multirow[t]{2}{*}{ Beijing } & Mar.31st 2014 & 07:00 to $10: 00$ p.m. & \multirow[t]{2}{*}{ Video-conferência } \\
\hline Interviewee 8 & MOE/NIES & & May 06th 2014 & $12: 00$ a.m. to $01: 30$ p.m & \\
\hline \multicolumn{6}{|c|}{ Government managers - Brazil interviewees } \\
\hline Interviewee 9 & DIFES/MEC & \multirow{5}{*}{ Brasilia } & & $10: 30$ as $12: 30$ & \multirow{5}{*}{ Presencial } \\
\hline Interviewee 10 & DIFES/MEC & & & 03:00 to $04: 20$ p.m. & \\
\hline Interviewee 11 & DIPES/MEC & & Aug.05th 2014 & & \\
\hline Interviewee 12 & SPO/MEC & & & 01:30 to $02: 30$ p.m. & \\
\hline Interviewee 13 & SPO/MEC & & & & \\
\hline
\end{tabular}

Source: Prepared by the author.

*Note: Although the organization Higher Education Strategy Associates (HESA) is not effectively governmental, it is the main provider of educational consulting service for the government, for which it is classified within the group "government" in this research.

Chart 2 - Respondents: higher education experts.

\begin{tabular}{|c|c|c|c|c|}
\hline \multicolumn{5}{|c|}{ Experts in higher education - Canada respondents } \\
\hline Denomination & University & Day & Schedule & Obs. \\
\hline Respondent 1 & York University & Feb. 18th 2014 & 09:15 to $09: 39$ a.m. & \multirow{6}{*}{$\begin{array}{l}\text { Online } \\
\text { website }\end{array}$} \\
\hline Respondent 2 & University of Ottawa & Jan.19th 2014 & 08:07 to $08: 18$ p.m. & \\
\hline Respondent 3 & York University & Jan. 25th 2014 & $03: 48$ to $04: 14$ p.m. & \\
\hline Respondent 4 & University of Toronto & Feb. 19th 2014 & 01:10 to $01: 38$ p.m. & \\
\hline Respondent 5 & York University & Oct. 22nd 2014 & $07: 56$ to $09: 15$ a.m. & \\
\hline Respondent 6 & York University & Oct. 16th 2014 & $08: 38$ to $09: 39$ a.m. & \\
\hline \multicolumn{5}{|c|}{ Experts in higher education - China respondents } \\
\hline Respondent 9 & York University & Mar 02nd. 2014 & 06:02 p.m. & \multirow{2}{*}{ E-mail } \\
\hline Respondent 10 & University of Tampere & Feb. 17th 2014 & 03:05 p.m. & \\
\hline Respondent 11 & East China Normal University & Feb. 19th 2014 & 04:54 to $06: 40$ a.m. & \multirow{6}{*}{$\begin{array}{l}\text { Online } \\
\text { website }\end{array}$} \\
\hline Respondent 12 & University of Toronto & Feb.08th 2014 & $08: 22$ to $08: 34$ a.m. & \\
\hline Respondent 13 & East China Normal University & Feb. 20th 2014 & $10: 59$ to $11: 31$ p.m. & \\
\hline Respondent 14 & Beijing Normal University & Feb. 07th 2014 & 02:05 to $02: 55$ a.m. & \\
\hline Respondent 15 & Peking University & Feb. 10th to 11 th 2014 & $11: 48$ p.m. to $12: 20$ a.m. & \\
\hline Respondent 16 & Tianjin University & Mar. 28th 2014 & 04:53 to $05: 10$ a.m. & \\
\hline \multicolumn{5}{|c|}{ Experts in higher education - Brazil respondents } \\
\hline Respondent 18 & Inst. for Labour and Society Studies (IETS) & Jul.20th 2014 & $06: 37$ to $07: 19$ p.m. & \multirow{7}{*}{$\begin{array}{l}\text { Online } \\
\text { website }\end{array}$} \\
\hline Respondent 19 & State University of Campinas & Sep 08th . 2014 & $07: 15$ to $12: 31$ a.m. & \\
\hline Respondent 20 & University of São Paulo - USP & Jul 21st. 2014 & 03:01 to $03: 34$ p.m. & \\
\hline Respondent 21 & Federal University of Goiás - UFG & Dec 15th . 2014 & $02: 22$ to $02: 44$ p.m. & \\
\hline Respondent 22 & Federal University of South Border - UFFS & Nov.06th 2014 & $03: 38$ to $05: 13$ a.m. & \\
\hline Respondent 23 & Federal University of Espirito Santo - UFES & Nov.13th 2014 & $10: 36$ to $11: 07$ a.m. & \\
\hline Respondent 24 & State University of Santa Catarina - UDESC & Nov.26th b 2014 & $03: 40$ to $05: 17$ a.m. & \\
\hline
\end{tabular}

Source: Prepared by the author. 
BBR

16,2

142

Chart 3 - Respondents: student leaders

\begin{tabular}{|c|c|c|c|c|}
\hline \multicolumn{5}{|c|}{ Student leaders - Canada respondents } \\
\hline Denomination & Organization & Day & Schedule & Obs. \\
\hline Respondent 7 & Can. Alliance of Student Assoc. (CASA) & Mar. 26th 2014 & $09: 28$ to $10: 26$ a.m. & Oplin wecite \\
\hline Respondent 8 & Ont. Undergrad. Student Alliance (OUSA) & Apr. 04th 2014 & 10:12 11:20 a.m. & Gintile wedsite \\
\hline \multicolumn{5}{|c|}{ Student leaders - China respondents } \\
\hline Respondent 17 & $\begin{array}{c}\text { Academic and Scientific Department in the } \\
\text { Postgraduate Association }\end{array}$ & Jan 12th. 2015 & $08: 19$ to $11: 19$ p.m. & Online website \\
\hline \multicolumn{5}{|c|}{ Student leaders - Brazil respondents } \\
\hline Respondent 25 & National Union of Students - UNE & Jan. 14th 2015 & 04:14 p.m. & Email \\
\hline Respondent 26 & $\begin{array}{c}\text { Union of Youth and Students in Brazil - } \\
\text { UJE }\end{array}$ & Nov.19th 2014 & 10:24 a.m. to $12: 09$ p.m. & Online website \\
\hline Respondent 27 & Central Directory of Students UFJF & Jan. 06th to 07 th 2015 & 02:17 p.m. to $06: 24$ a.m. & \\
\hline
\end{tabular}

Source: Prepared by the author.

deepen the articulation of the tuition fees charging in higher education in three countries essentially different (culturally and economically): Brazil, Canada and China.

The exploratory study is guided by the comparative multi-case analysis, which for Schneider and Schimitt $(1998$, p.1) helps the researcher to:

[...] discover regularities, perceive shifts and changes, build models and types, identify continuities and discontinuities, similarities and differences, and specify the most general determinations that govern the social phenomena.

From then on, direct approach collection techniques were applied, by conducting semi-structured interviews and questionnaires. The target audience comprised the key stakeholders in the system:

a. Government managers: Government service professionals in their respective countries, responsible for effective public policies in higher education;

b. Experts in higher education: Professors and researchers who have as one of their main fields of study the issue of higher education in some of the studied countries;

c. Student Leaders: Leaders who are ahead of student unions that represent the students' audience of each of the studied countries.

The list of interviewees is presented in Chart 1, contemplating the participants' agency, the denomination used in the research, the city where the interview took place, date, time/duration and a last call column observation, in which it indicates whether the interview was in person or by video conference.

To analyze the experts' perception in higher education and student leaders of the three countries, unstructured questionnaires were used. The advantage of using this tool is to save resources for execution, providing time-saving, cost, travel, besides not being influenced by the interviewer (MARCONI; LAKATOS, 1990).

The experts in higher education who answered the questionnaire are shown in Chart 2, considering the denomination used in the research, the university, the date, time/duration that the questionnaire was answered, and the last column called observation, in which it 
indicates whether the respondent sent the answers via online dedicated website or opted to perform sending by email.

The list of student movements leaders that responded to the questionnaires is presented in Chart 3, considering the denomination used in the research, the student organization to which he or she belongs to, date, time/duration that their questionnaire was answered. In addition, the last column called observation, in which it indicates whether the respondent sent the answers via dedicated online website or opted to perform sending by email.

For the qualitative treatment, the data collected through unstructured questionnaires and semi-structured interviews were treated using the content analysis technique as reference, using the MAXQDA 10 software, in order to confirm or refute the findings.

\section{RESULTS}

The results show participants' perceptions regarding the tuition fees charging, initially describing Brazil, followed by Canada and China.

\subsection{BRASIL: TUITION FEE CHARGING AND ITS PARADIGM IN THE PUBLIC HIGHER EDUCATION INSTITUTIONS (HEIS)}

In Brazil, the Public Higher Education is $100 \%$ free. In other countries, such as Canada and China, there is a Tuition Fee charging, where students bear, on average, $30 \%$ of the total cost of their higher education.

Based on this premise, it was investigated with the participants whether they believe tuition fees charging to be feasible in Public Institutions of Higher Education in Brazil and whether they see some prospect of such fees charging in universities.

\section{a) Government}

Government leaders have shown to be radically against the charging of any fee in public institutions of higher education, particularly in federal universities. In addition, they reported that there is no prospect for any action in this regard.

Interviewee 9 believes that Brazil has two systems, the pure free through federal funding and the other in which the government contributes with a part, and the private sector contributes with the other one, that receives the scholarships and the student contributed with another part. Interviewee 11 goes further by asserting that the government " by no means" in making such charges, an action that would be necessary including the Brazilian constitution, which says that education in public institutions is free.

Interviewee 10 reports that some people have defended the charging hypothesis, but the appointed reasons were not sufficient to improve the debate on this action.

It has thought of something. There are economists and thinkers who speak of it, that you have an individual advantage with higher education. But if so, 
BBR

16,2

144 we will have to charge in the SUS [Acronym which means Unified Health System], because when I go there ill and I am treated, I have a personal advantage. Thinking like that, we have to charge for many public services (INTERVIEWEE 10).

Corroborating with the understanding of the above leaders, Interviewee 9 reinforces that Brazil has health and education with this free premise and that it is not wrong in relation to other countries, each one just found their own way. However, Interviewee 11 reports that OECD argues for charging fees, and that the government has been asked why not adhere to this practice.

They cannot see, but our model is not so unique neither. If you go to Germany, everything is free. In several European countries, everything is free. So they are just looking at themselves, that's why, as there are very different models in other countries. And I think we chose a model today, hybrid. If by any chance it is possible to be identified as hybrid, since we have $76 \%$ of enrollments in the private sector but in the private sector the government goes with the direct appeal. Thus, strictly speaking, at least $51 \%$ of enrollments today are already public. This is the method by which it was opted for (INTERVIEWEE 11).

Fearing any initiative for the fees collection, Interviewee 13 believes that to start this process, there is the possibility of public institutions to exclude the population with low income.

Finally, Interviewee 11 realizes that in the entire system, there is a balance in favor of democratization, because it allows for an equitable treatment to the rich and the poor in the process. The interviewee reaffirms not agreeing if the paid public education is instituted, it will be a more accurate system. While institutions can garner more resources to the fees collection, these resources can be obtained by part of the income tax of a more economically favored population, for example. The issue is the Federal Government always seeking for a fairer alternative to decide how to behave.

b) Experts in Higher Education

Corroborating the views of the government managers, experts also show that fees collection in public institutions would not be feasible. If the idea is to diversify sources of funding, other alternatives could be considered, such as taxation on higher incomes or the search for a contribution from the graduate students when they return to society.

Initiating the debate, Respondent 23 ensures that this is a difficult discussion to the federal universities, since they are in a development phase and need to expand higher education for the large population still without access to it.

For Respondent 20, charging fees does not achieve expansion. The expert says that when fees were charged at the time of the military dictatorship, it simply replaced one source with another and the budget was of the same size. 
According to Respondent 21, this has been an issue debated in Brazil for many years and has already been implemented in some institutions and subsequently repealed. The understanding that prevails is that the offer must be public. If it is considered that democratization is happening on this educational level, through political quotas and other actions that have allowed access to low-income and ethnically diverse, it is not consistent to take an action like this, a view also shared by Respondent 22 .

The Brazilian social scene is uneven markedly. Therefore, gratuitousness is a decisive factor for the democratization of any level of education. I am among those who consider education at any level, a right. So, it is not an expenditure, but an investment. Therefore, I am totally against the charging of any tuition fees in HEIs (RESPONDENT 22).

For Respondent 24, considering the term "feasible" within the legal precepts, the fees adoption is not credible, given the audit of Government Ministries for public universities not to charge anything.

Respondent 19 explains that today, even with an unfair tax system, Brazil is in the range of 35\% of GDP regarding the tax collection. Therefore, it suffices to enter the club of countries that are in the range of the $40 \%$ as is the case of Norway, Austria, Finland, Denmark, Sweden, France, Belgium, Italy, among others, designed for the surplus for education to reach the goal of $10 \%$ of GDP proposed by the National Plan of Education (PNE).

Finally, in a complementary way, Respondent 20 suggests that it might require certain commitments from students who return to society instead of a direct student's charging during their formative process.

c) Student Leadership

The student leaders also did not consider feasible to start a fee-charging process in public institutions, on the contrary, they argue that the public and free institutions receive even more students.

According to Respondent 25, the fees charging imposed socio-economic barriers to education access, which needs to be treated as a social and Federal Government responsibility as well as to ensure equal access to all.

Although not agreeing with the fees charging, Respondent 26 believes that in the distant future, it may so happen, especially if they lack resources to promote the expansion of education. Moreover, the student leader reports a failure experience with the fees charging in a recent time.

There are experiences where UEMG (State University of Minas Gerais), tried encamping institutions within the state from the late 90's and early 2000, where tuition and students would bear $50 \%$ of the course and the government would be charged with the other share, yet the idea and experience was not fruitful because the students of these institutions had no way to afford this payment (RESPONDENT 26). 
BBR

16,2

Finally, Respondent 27 shows what the student movement aspiration is.

What we want is the democratization of education and that all social classes are in the classroom, we believe that education must be free, public and with quality (RESPONDENT 27).

\subsection{Tuition FEes In CANAdA AND THEIR RELATION TO THE SYSTEM MAINTENANCE AND EXPANSION}

Unlike Brazil, Canada has its totality of higher education offered by the public system, but it charges tuition fees from its students. Once this scenario is known, this section seeks to understand with the government, the experts and student leaders, what the perspective behind the charging of tuition fees is, how this fee may be related to the expansion and system quality and perception of a public higher education $100 \%$ free.

\section{a) Government}

The government leaders unanimously favor the tuition fees charging in public universities. However, they demonstrate that a good student assistance system is necessary so that the access from the socially excluded is not jeopardized. Once one has this concern, there is a part of them, which guarantees that the tuition fees charging does not reduce the percentage of enrollment and access.

For Interviewee 1, there is no clear relationship between having tuition fees on ones system and the ability to promote access to higher education, on the contrary, he believes that fees have a certain ability to make larger and better systems because, simply, they help to increase the financial resources within the system. This view is reinforced by Interviewee 2 , who advocates in favor of the charges saying that research has shown that fees do not really affect access.

Interviewee 4 also appears to be favorable for tuition fees charging, saying that traditionally, people who go to higher education are from middle and upper classes, and they can afford these costs, there is no reason for this level of education to be subsidized to them. Another point systematically defended by both Interviewee 3 and Interviewee 4 , are the private gains that a graduation can offer to an individual. On the other hand, Interviewee 5 believes that this process goes against the culture of the country itself.

Canadians do not like to see things being delivered for free, but they also do not like to pay too much. It cannot be free, since access would be very low. It cannot be very expensive because it is difficult to pay (INTERVIEWED 5).

According to Interviewee 4, there is a very specific return on investment in higher education, and the government's intention is not to harm the participants and not to charge exorbitant fees. The government's philosophy is to charge fees to cover around one third $(1 / 3)$ of the actual cost to educate a student.

When asked regarding the full gratuity in public higher education, leaders have shown that such a measure would not be beneficial to the system. 
We actually think that a free system would not be accessible to the underrepresented students like the system we currently have. So what we do, we have a very generous financial assistance plan for the most needy students (INTERVIEWEE 4).

Finally, Interviewee 5 admits that there were some debates about $100 \%$ free public higher education in the 60's and 70's, but in no opportunity this idea proved to be representative, and he personally believes it never will, because they need the tuition fees to feed the system.

b) Experts

Specialists in higher education do not act radically against totally free public higher education; however, they act cautiously when addressing the issue, because, at the time, the fees are absolutely essential to the proper functioning of the system.

For Respondent 5, the government wants students to pay the tuition fees, as when someone makes a personal investment, this individual becomes more engaged. Respondent 2 complements this idea, believing that tuition fees are a balance of political pressures, concerns about access, needs to increase revenue for the system, and a sense that those who benefit should pay at least a part of the education they receive. For Respondent 4, it is a more complex situation, since the whole formation process cannot be charged from all, since it is used only by a part of society.

Respondent 1 presents a different view about the fact. For him, Universities in general, would like to charge higher tuition fees, which would be ideal for the government. However, it is not politically feasible, because middle-class families are reluctant to pay more. A student's protest that took place in the province of Quebec in 2013 against rising fees meant that the government is worried about it. The deregulated fees also bring harm to the system, as Respondent 6 accounts, because it makes certain programs become unaffordable for many. However, the perspective of high tuition fees is still difficult for the government to understand, so it always tries to moderate the increase in fees, but with no prospect of eliminating them.

When analyzing the prospect of removing the tuition fees from the current model, some experts are skeptical. Respondent 5 reports that he does not see Ontario as going towards a teaching model $100 \%$ free, because the cost of higher education sector operation is significant and cannot be carried alone by the taxpayer. Respondent 2 is even harsher in his assessment, classifying the measure as a "bad policy."

No tuition fees charging is a bad policy when it comes to efficiency, equity and equalization of public finances (RESPONDENT 2).

On the other hand, some experts classify the measure as valid, since the government honor its obligations and continues financing the system with an amount similar to the model with the fees. Respondent 3 states that it has no objection to a higher education system $100 \%$ free, since the government provides the money that currently comes to universities through tuition fees. For the specialist, universities cannot work without money, they need adequate funding, otherwise it will have access, but for one those not 

current model.

My view is that higher education, in the ideal world, would be free. But it will never happen. Moreover, students do not understand that free higher education limits access because it means that universities need to offer fewer seats in higher education. In places where the tuition fees are higher in Canada, access is also higher on the other hand, and the access is lower in provinces where tuition fees are lower (RESPONDENT 1).

c) Student Leadership

The student leaders have shown slightly contrary opinions on this issue, although both agree that tuition fees are relevant for the proper functioning of the system.

For Respondent 7, who operates in a student organization nationwide, tuition fees are an important source of funding for most higher education programs. He also believes that they encourage programs to see students more than just an expense, as they also offer a hand.

On the other hand, Respondent 8 , who operates in a student organization of provincial scope, shows dissatisfaction with the fees charged in Ontario. He reports that the tuition fees have been the means by which universities offer education and expand their own operations in the context of decline or stagnation of other forms of government funding for higher education in Ontario.

OUSA believes that a fair cost-sharing model is one in which students pay less than at present, and no more than one third of the total cost of the training for a student through tuition fees. OUSA would support any move toward tuition fees reduction (RESPONDENT 8).

Regarding the complete tuition fees abolition, both student leaders believe that such a measure would bring more losses than profits for Canadian higher education system. According to Respondent 7:

If there were a significant increase in levels of funding for universities, which according to the current financial policy is unlikely, this change would still have a greater impact on access to prioritize grants and loans, to maintain the level that was previously covered by tuition fees (RESPONDENT 7).

On the other hand, Respondent 8, despite of being unhappy with the amount of fees charged in Ontario, recognizes that students must bear at least some part of their education, due to significant personal benefits that come with having a higher education. $\mathrm{He}$ also strengthens that there is evidence to support the charge of an academic rate that may decrease dropout rates and increase individual students' performance. 


\subsection{TUITION FEES AND THEIR ROLE IN THE REMARKABLE EXPANSION BBR OF THE CHINESE SYSTEM

Like Canada, but as a more recent strategy, China also began to collect tuition fees in its public universities, which were central, provincial or local.

In this section, we sought to understand what the government's perspective on the tuition fees charging is and if this charge is related to the expansion and system quality. As asked to Canadians, it was also investigated with the Chinese participants the opinion of a $100 \%$ free education (free from tuition fees).

\section{a) Government.}

According to the government managers' perception, tuition fees charging was an absolutely essential process to ensure the expansion and democratization of the system. Due to the large volume of people interested in joining higher education and the cost that this demand would bring to the public coffers, dividing the portion with the main beneficiaries was the solution found by China. None of the leaders consider the possibility of China returning to a completely free public system. Interviewee 7 tells about the beginning of the tuition fees charging in the country.

You need to be aware of the fact that China provided free higher education by the end of 90's. At that time, China realized that it would not be able to expand using only its economy, then it chose to begin collecting fees, and it was in the 90's period which the expansion of higher education truly happened (INTERVIWEE 7).

According to Interviewed 8 , the Chinese government realized a global provision for the charging of fees.

In the government's perspective, charging tuition fees is a universal trend. On one side, higher education is not compulsory, so the student should rather pay fees for this level of education. On the other hand, the government cannot afford more money because the number of students is currently too large (INTERVIEWED 8).

Regarding the complete tuition fees elimination, making the Chinese educational system completely free, Interviewee 8 appears to be a nonbeliever with this action. For the interviewee, education in China is expanding and there are increasingly more students in universities. If the students do not pay the tuition fees, universities cannot afford the costs to provide the under graduation of these students. For this reason, he believes that the Chinese government does not intend to provide a $100 \%$ free education, opinion also advocated by Interviewee 6 . 
BBR

16,2

150
The government believes that higher education brings a public benefit to society, and to the private sector, for the individual, and then it is not reasonable to adopt a totally free model for this level of education (INTERVIEWEE 6).

Finally, Interviewee 6 strengthens that China has to charge tuition fees that are possible to be paid by students, but this process only began to be absolutely necessary so that they reach the desired indicators for this level.

b) Experts

As university leaders, experts in higher education advocate the tuition fees charging in the Chinese higher education system. They consider this issue closely connected with the system expansion and stability, believing it is impossible for such a large nation to fully assume the costs for this level of education, which is not compulsory.

Respondent 11 argues that, no doubt this policy was responsible for the expansion of higher education that took place in 1999. Respondent 13 also supports this initiative.

It is reasonable to charge for higher education and that users of the system to share part of the cost in higher education by paying tuition fees. This is beneficial for improving the quality and expansion of higher education (RESPONDENT 13).

For Respondent 10, tuition fees charging served to ease the government's financial pressures. With incentives charging fees, both the government and HEIs tend to enroll more students.

Respondent 12 explains that in many ways, the tuition fees structure is similar to Canada: public universities fees cover about $20 \%$ of the actual cost, and is available for most students.

When asked about the tuition fees exclusion, experts argued not to believe that it would be the best option. For Respondent 16, tuition fees are closely related to the expansion in enrollment, it would not be advantageous to the nation not collecting them. The same line of reasoning is stated by Respondent 10, who realizes a worldwide trend towards recovery, so he does not believe that gratuity for higher education is an option.

Finally, Respondent 15 supports the effectiveness of the charging policy, especially because it is accompanied by a series of assistance tools.

Tuition fees charging is a way to expand enrollment beyond the budgetary capacity that is provided by the state. In China, I think the tuition fees policy is efficient and equitable. In fact, it works well, as there are also financial aid and loans for needy students (RESPONDENT 15).

c) Student Leadership

Respondent 17 also shares the same opinion of experts and government managers. According to the student leadership, the fees have an important role in the Chinese higher education system and removing them would not be a good initiative. 
For Respondent 17, the fees should be maintained, and argues that without them there would be no guarantee of any quality to the participating students. The student leadership also analyzes a hypothetical scenario without charging fees.

Artificially, not charging tuition fees could help in the expansion of higher education, since the doors would be open to all. However, it is not feasible in the current country's condition (RESPONDENT 17).

Finally, the student leadership argues that the charges should continue, but it is necessary to review some factors, especially the student's assistance tools, which are essential to ensure the students' democratization of access and permanence in universities.

\section{CONCLUSIONS}

This research aimed to understand all the aspects behind the tuition fees charging in Canada and China, and to understand the Brazilian view about this fact. The data showed that the tuition fees charging are seen as necessary by Canadian and Chinese participants and that this subject is still a paradigm in Brazilian territory.

This structural difference observed in the Canadian and Chinese systems (the existence of the tuition fees charging in public institutions of higher education) is an extremely controversial issue in the Brazilian territory, but it was possible to verify evidence of the charging fees effectiveness for the expansion and quality assurance along the studied systems. As the Canadian system has been performing fees charging for over 50 years, it is more difficult to prove its effectiveness quantitatively, except for the fact that it is one of the best well-funded systems in the world, as shown in the analysis of general indicators for higher education. However, qualitatively, the participants defended fees charging as absolutely essential for the expansion and maintenance of higher education system.

In the case of Chinese higher education, fees collection have been charged in all institutions for at least 20 years (1997), which facilitates the understanding of the true impact on the system, and it was possible to quantitatively prove that the Fee-Charging Policy was one of the main actions that promoted the expansion of the Chinese higher education and therefore of its economy. To support this idea, the participants questioning about the real importance of the fees collection within the system was carried out, and all unanimously, recognized how essential this measure was. It is worth noting that many of these participants experienced the beginning of the fees collection, either as students or already as professors, but nevertheless they acknowledged that it was a real watershed for transforming the Chinese higher education system in the world's largest in terms of quantity.

However, from the moment charging in public institutions of higher education begins, there is a risk of under-represented groups being excluded from the system. They also supported the idea that a system is fairer and more democratic if it is levied on those who have the means to pay, and student assistance is offered to those who cannot afford to pay.

Then, in order to understand the perception of Brazilian participants, the possibility of charging fees in the public system was surveyed, an option completely rejected by virtually all participants, reinforcing a cultural barrier around this issue. 
Briefly, although interviewees and respondents from Brazil demonstrate a different positioning of respondents and interviewees from Canada and China, it should be emphasized that in qualitative studies, there are no general conclusions, since the sample is not representative of the population. In this perspective, the research presented an overview about the perspectives around the theme, in order to stimulate further reflections and debates.

It is also necessary to highlight the limitations of this research regarding the use of the qualitative methodology. Although this methodology allows a deeper and closer contact with the objects of study, each observation is unique and depends on the objects, the researchers and the participants. In addition, both investigators and investigated are agents, which implies the risk of losing objectification, based on the investigator's subjectivity.

Another limitation refers to aspects that could not be contemplated, since the sector chosen for research (educational) is a very problematic sector, due to a series of conjunctural and even structural factors of each country. For this reason, it was not possible to study all these aspects in only one research, delineating the research in the perspectives around the tuition fees collection.

Based on the limitations presented, we suggest the continuity of this research, recommending for future studies a quantitative research that objectively shows the collection of the countries studied with the tuition fees charging and, from then on, a simulation of the Brazilian case, considering the universe of students eligible to pay fees. We also suggest a study that can contribute to these reflections including new variables, since the demography, economy, politics and social environment can affect each country differently. The study of the macroeconomic environment of each country can help to understand its possible effects on the tuition fees collection, considering aspects such as the availability of financial loans, unemployment rates, level of employability for students with a higher degree, among other factors. This type of analysis would contribute this research to map countries in which the population has a greater predisposition to pay academic fees in relation to other countries that have lower predispositions.

Finally, it is understood that this reflection is necessary, especially if proven the need to increase financial support to higher education institutions and such action cannot be performed due to the government's financial unavailability.

\section{REFERENCES}

ARMIJO, L. E. The BRICs Countries (Brazil, Russia, India, and China) as Analytical Category: Mirage or Insight? Asian Perspective, Portland, v. 31 n.4, p. 7-42, 2007.

ARWU. Academic Ranking of World Universites 2014. Center for World-Class Universities of Shanghai Jiao Tong University. Shanghai. China. Disponível em: $<$ http://www.shanghairanking.com/ARWU2013. html>. Acesso em 21 de Fevereiro de 2015.

BANCO MUNDIAL. Relatório sobre o Desenvolvimento Mundial 1997. Washington - USA, 1997.

CARNOY, M.; RHOTEN, D. What Does Globalization Mean for Educational Change. Comparative Education Review, 46 (1), p. 1-9, 2002.

COLLIS, Jill; HUSSEY, Roger. Pesquisa em Administração. 2nd. ed. Porto Alegre: Bookman, 2005.

DIDRIKSSON, Axel. La Universidad del Futuro: relaciones entre la educación superior, la ciencia y la tecnologia, 2nd. ed. México: CESU-Universidad Nacional Autónoma de México/Plaza y Valdés. 2000.

ERNST, D. Pathways to innovation in Asia's leading electronics-exporting countries: a framework for exploring drivers and policy implications. Int. J. Technology Management, Olney, v. 29, n. 1/2, p. 6-20. 2005. 
EUROPEAN COMMISSION. Anual Growth Survey: Progress report on Europe 2020. Brussels, COM (2011) $11-\mathrm{a} 1 / 2.2011$.

GIAMBIAGI, F.; ALÉM, A. C. Finanças públicas: teoria e prática no Brasil. 2nd. ed. Rio de Janeiro: Campus, 2001.

HADDAD, Sérgio; GRACIANO, Mariângela. Educação: direito universal ou mercado em expansão. São Paulo Perspec., São Paulo, vol.18, n.3, pp. 67-77, 2004.

HAYES, Dennis. Behind the silicon curtain: the seductions of work in a lonely era. London: Free Association Books. 1989.

HEEACT. Performance Ranking of Scientific Papers for World Universities Project in 2011. Taipé, Taiwan. Available in: <http://ranking.heeact.edu.tw/>. Accessed on February 21, 2015.

ILON, L. Higher Education Responds to Global Economic Dynamics. In: RUST, V.; PORTNOI, L.; BAGLEY, S. (Orgs.). Higher Education, Policy and the Global Competition Phenomenon. New York: Palgrave Macmillan, 2010.

LAZERSON, M. Higher Education and the American Dream: Success and its Discontents. Budapest: Central European University Press, 2010.

LERDA, Juan Carlos; ACQUATELLA, Jean; GÓMEZ, José Javier. Coordinación de políticas públicas: desafíos y oportunidades para una agenda fiscal-ambiental. In: ACQUATELLA, Jean; BÁRCENA, Alicia (Orgs.). Política fiscal y medio ambiente: bases para una agenda común. Santiago de Chile: Comisión Económica para América Latina y el Caribe (CEPAL)/ONU, p. 65-88. 2005.

LONGO, Carlos Alberto. Finanças Públicas: Uma Introdução. São Paulo: FIPE/USP, 1984.

MARCONI, M. A.; LAKATOS, E.M. Técnicas de Pesquisa. 2nd. ed. São Paulo: Editora Atlas, 1990.

MAHMOOD, P. I.; SINGH J. Technological Dynamism in Asia. Research Policy, Vol. 32, N. 6, p. $1031-1054$. 2003.

MATIAS-PEREIRA, J. Finanças públicas: a política orçamentária no Brasil. 3rd. ed. São Paulo: Atlas. 2006.

SAWAYA, Rubens R. Crise: um problema conjuntural ou da lógica da acumulação mundial?. Estud. av., São Paulo, v. 23, n. 66, 2009.

SCHNEIDER, Sergio; SCHIMITT, Cláudia Job. O uso do método comparativo nas Ciências Sociais. Cadernos de Sociologia, Porto Alegre, v. 9, p. 49-87, 1998.

TÜNNERMANN BERNHEIM, C. La educación superior necesária para el siglo XXI. In: LOPEZ SEGRERA, F.; RIVAROLA, D.M. (Orgs.). La universidad ante los desafios del siglo XXI. Asunción: Ediciones y Arte, p. 25-69. 2010.

WEBOMETRICS. Ranking Web of Universities: January 2015 edition. Madrid, Espanha. Available in: $<$ http://www.webometrics.info/en/world>. Accessed on February 12, 2015. 